\title{
NON-STANDARD MONETARY POLICY MEASURES FOR SELECTED CENTRAL BANKS
}

\author{
Vesna Martin ${ }^{1}$ \\ The National Bank of Serbia, Belgrade, Serbia ${ }^{2}$
}

\begin{abstract}
The main focus of this paper is presentation of non-standard monetary policy measures of selected central banks. The banks which are subject of analysis are Federal Reserve Bank, European Central Bank, Bank of England and Bank of Japan. All the aforementioned central banks have begun to apply non-standard monetary policy measures since the global financial and economic crisis, which has led that inflation rate in a long-term be below the target level. In case of the Federal Reserve Bank nonstandard policy actions were implementing to put downward pressure on real longer-term interest rates and more generally to improve overall financial and economic conditions. The European Central Bank goal in using non-standard monetary policy is to return inflation rate to levels below, but close to, $2 \%$ over the medium term, while in case of the Bank of England it was response to the North Atlantic banking crisis and to a sharp downturn in domestic economic prospects. The Bank of Japan aim is to fight against deflation and to reach inflation target of $2 \%$.
\end{abstract}

Keywords: non-standard monetary policy measures, global financial crises, quantitative easing

\section{INTRODUCTION}

Quantitative easing is an unconventional monetary policy in which a central bank purchases government securities or other securities from the market in order to lower interest rates and increase the money supply. Quantitative easing increases the money supply by flooding financial institutions with capital in an effort to promote increased lending and liquidity. When short-term interest rates are at or approaching zero, and when the printing of new banknotes isn't an option, quantitative easing can be considered (https://www.investopedia.com /terms/q/quantitative-easing.asp). What is common to all economies covered by the crisis is the circulation of contaminated capital in the form of nonperforming loans and speculation in the field of financial derivatives and hedges funds (Bašić, 2012, p. 3). Financial and economic crises, which started in 2007 in USA, had influence on global central banks to implement non-standard monetary policy measures, which were ranging from liquidity and credit facilities to asset purchases and forward guidance. These measures restore market functioning and confidence,

\footnotetext{
${ }^{1}$ martinv0803@hotmail.com

${ }^{2}$ The views expressed in this paper are those of the author and do not necessarily represent the official view of the National Bank of Serbia
}

Vol. 21, бpoj 1/2019, cmp. 35-52 
facilitated the transmission of monetary policy and supported economic activity.

The reversal of the housing boom in the United States and the collapse of the US sub-prime mortgage market resulted in a crisis of a global dimension in 2008. In the euro area, the economic and financial collapse escalated into a sovereign crisis in 2010 (Fratzscher et al., 2014, p. 4). Central banks have been forced to review their implementation frameworks and to try out policies that, only a few years back, were not on their radar screens (Borio \& Disyatat, 2010, p. 33). In addition to easing monetary policy through conventional means (i.e. lowering shortterm interest rates), central banks introduced a set of so-called nonstandard policy measures to address the implied challenges. The design of these measures varied from one jurisdiction to another (Lenza et al., 2010, p. 5). The aim of monetary policy was to achieve low and stable inflation, the policy framework was inflation targeting, the instrument was a shortterm interest rate at which the central bank provided funds to banks or the interbank market and the impact of this official rate on market rates and the wider economy was reliably quantified (Joyce et al., 2012, p. 271). After the intensification of the crisis, policy rates were rapidly lowered toward their effective lower bounds in early 2009. In parallel, the assets on central bank balance sheets have in many economies grown to an unprecedented size reflecting unconventional monetary policy measures taken to provide liquidity to ailing financial sectors and to support faltering economies through lower long-term interest rates and financial market risk premium (Gambacorta et al., 2014, p. 618).

There are four channels through which unconventional monetary policy affects the financial sector. First, reducing the risk-free rate lowers the hurdle rate for risky investment projects. Second, unconventional policy may lead some financial institutions to seek higher returns, due to institutional dissatisfaction with low yields. Third, by promoting recovery in the real economy, unconventional policy lowers delinquency and default rates, raises profits and possibly lowers risk aversion. Fourth, low interest rates reduce the opportunity cost of holding reserves or collateral (Chodorow-Reich, 2014, p. 156). Central banks must ensure that any unconventional policy measures they implement are clearly communicated and aimed squarely at achieving their mandated objectives and nothing more (Santor, 2013, p. 10).

The hypothesis from which this paper starts is that non-standard monetary policy measures have favored economic recovery and the stabilization of economic growth. The used methods of analysis are inductive and deductive analysis, method of analysis and synthesis, classification method and comparison method. This paper is organized in 
following order. For each selected central bank it is presented nonstandard monetary policy measures which were or still using with dynamics of implementation and size of each program. After this it is presented comparative analysis with recommendation for future actions. The results of using non-standard monetary policy are presented with its influence on economy.

\section{NON-STANDARD MONETARY POLICY MEASURES OF THE FEDERAL RESERVE BANK}

By the end of 2008, the Federal Reserve's conventional monetary policy tool, the federal funds rate, was at its effective lower bound as the economy was in the midst of a financial crisis and deep recession. Unconventional policy actions were intended to put downward pressure on real longer-term interest rates and more generally to improve overall financial conditions, including bolstering prices for corporate equities and residential properties (Engen et al., 2015, p. 3).

Federal Reserve Bank (FED) had been using four program of nonstandard monetary policy and these programs are: Quantitative Easting 1 (QE1), Quantitative Easting 2 (QE2), Maturity Extension Program (MEP) and Quantitative Easting 3 (QE3) (https://www.federalreserve.gov/).

QE1 FED announced in November 25, 2008 when initiate a program to purchase the direct obligations of housing-related government-sponsored enterprises (GSEs) - Fannie Mae, Freddie Mac and the Federal Home Loan Banks - and mortgage-backed securities (MBS) backed by Fannie Mae, Freddie Mac and Ginnie Mae. Purchases of up to $\$ 100$ billion in GSE direct obligations under the program are conducted with the Federal Reserve's primary dealers through a series of competitive auctions. Purchases of up to $\$ 500$ billion in MBS were conducted by asset managers selected via a competitive process with a goal of beginning these purchases before end 2008. At the meeting, which was held at January 28, 2009, Federal Open Market Committee (FOMC) announced that it is ready to expand $\mathrm{QE}$ and buy Treasuries. At it's next monetary policy meeting held at March 18, 2009, FOMC decided to increase the size of the Federal Reserve's balance sheet further by purchasing up to an additional $\$ 750$ billion of agency MBS, bringing its total purchases of these securities to up to $\$ 1.25$ trillion that year and to enlarge its purchases of agency debt that year by up to $\$ 100$ billion to a total of up to $\$ 200$ billion. Moreover, to help improve conditions in private credit markets, the Committee decided to purchase up to $\$ 300$ billion of longer-term Treasury securities over the next six months. In statement, which was released in August 12, 2009, FOMC has decided to 
gradually slow the pace of transactions and anticipates that the full amount will be purchased by the end of October, but at the end of September 2009 the Committee announced extention of QE1 by the end of the first quarter of 2010. In November 2009 FOMC decided to downsize size of agency debt from $\$ 200$ billion to $\$ 175$ billion. In August 2010 FOMC declare support to the economic recovery in a context of price stability and decided to keep constant the Federal Reserve's holdings of securities at their current level by reinvesting principal payments from agency debt and agency mortgage-backed securities in longer-term Treasury securities. In this statement FED officialy ends QE1.

QE2 FED officially announced in November 3, 2010 when the Committee annunciated further purchase $\$ 600$ billion of longer-term Treasury securities by the end of the second quarter of 2011, a pace of about $\$ 75$ billion per month. Program QE2 was finished in June 6, 2011, when the Committee announced that it will terminate its purchases of $\$ 600$ billion of longer-term Treasury securities by the end of that month and will maintain its existing policy of reinvesting principal payments from its securities holdings.

MEP FED introduced in September 21, 2011 when decided to purchase, by the end of June 2012, $\$ 400$ billion of Treasury securities with remaining maturities of 6 years to 30 years and to sell an equal amount of Treasury securities with remaining maturities of 3 years or less. This program should put downward pressure on longer-term interest rates and help make broader financial conditions more accommodative. In June 2012 FOMC decided to continue through the end of that year MEP program to extend the average maturity of its holdings of securities.

QE3 officially started to implement in September 13, 2012 when FOMC decided to increase policy accommodation by purchasing additional agency mortgage-backed securities at a pace of $\$ 40$ billion per month and in December 2012 added purchases of Treasury securities at a pace of $\$ 45$ billion per month. In December 2013 FOMC decided to decrease size of QE3 program in a way that holdings of agency mortgagebacked securities will be at a pace of $\$ 35$ billion per month rather than $\$ 40$ billion per month and holdings of longer-term Treasury securities will be at a pace of $\$ 40$ billion per month rather than $\$ 45$ billion per month. At the next monetary policy meetings, which were held in 2014 (January 29, March 19, April 30, June 18, July 30 and September 17) FOMC decreased on each meetings size of purchase agency mortgagebacked securities and longer-term Treasury securities in level of $\$ 5$ billion for both types of securities. In October 29, 2014 FOMC officially completed its application of QE3 and stated that maintaining its existing policy of reinvesting principal payments from its holdings of agency debt 
and agency mortgage-backed securities and of rolling over maturing Treasury securities at auction. This policy, by keeping the Committee's holdings of longer-term securities at sizable levels, should help maintain accommodative financial conditions.

One of the indicators which can point to the exit from the crises is interest rate, like effective federal funds rate in US. The efective federal funds rate is the interest rate at which depository institutions trade federal funds (balances held at FED) with each other overnight and basically represent weighted average rate for all of these types of negotiations is called the effective federal funds rate (Graph 1). During the global financial crises this rate was at the low level (in period from September 2008 till May 2017 below 1\%) and with economic recovery the rate started to rise.

Graph 1.: Effective Federal Funds Rate (in \%, monthly level, not seasonally adjusted)

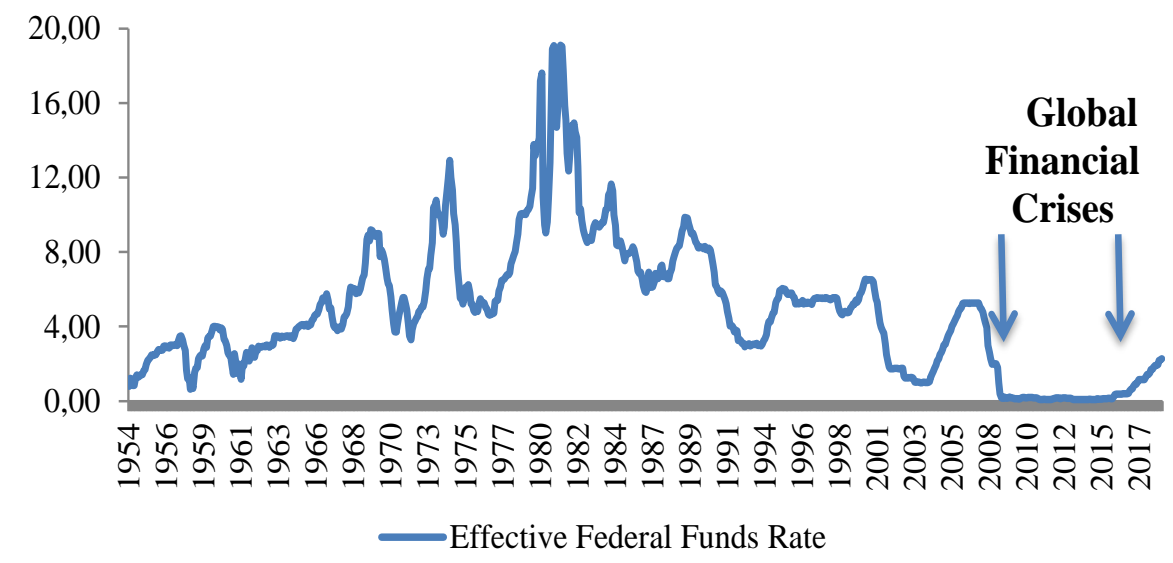

Source: Economic Research Division, Federal Reserve Bank of St. Louis

After competition of non convention measures FED started with normalization of monetary policy. In case of FED normalisation means gradually raising its target range for the federal funds rate and gradually reducing the Federal Reserve's securities holdings. At the monetary policy meeting at December 16, 2015 FOMC votes to increase the target range for the federal funds rate to $1 / 4$ to $1 / 2$ percent, which was first rate increasement since June 2006. At its September 2017 meeting, the FOMC agreed to start the program for gradually reducing the Federal Reserve's securities holdings starting from October 2017. Also non-standard monetary policy contributed to improvement of economic indicators. In 
November 2018 inflation rate is at the level of 2.2\% YoY, which is higher than the rate in November 2008 (1.1\% YoY) when FED started with implementation of QE1 (target rate of inflation is set at $2 \%$ on annual level). In November 2018 unemployment rate is at the level of 3.7\% (in November 2008 at 6.8\%). (https://www.bls.gov/)

\section{NON-STANDARD MONETARY POLICY MEASURES OF THE EUROPEAN CENTRAL BANK}

The first consequences of the financial crisis in the European area were illiquidity and losses due to the depreciation of assets covered by mortgage securities and their financial derivatives (Stojković\&Gašić, 2012 , p. 45). At the peak of the European crisis in 2012, the anxiety about excessive sovereign debt led to government bond yield for countries in the European periphery that were consider unsustainable and thereby endangered the Eurozone as a whole. In response, the president of the European Central Bank (ECB), Mario Draghi, introduces the Outright Monetary Transactions (OMT) program by stating on July 26, 2012, during a conference in London that , , [...] the ECB is ready to do whatever it takes to preserve the euro. And believe me, it will be enough" (Acharya et al., 2017, p. 3).

The main objective of the non-standard measures introduced by the Eurosystem was the expansion of central bank intermediation. This was intended to substitute for interbank transactions that could no longer take place owing to the malfunctioning private money market (Giannone et al., 2011, p. 16). Unconventional monetary policy shocks are characterized by a significant shift in the monetary base or the balance sheet size of the Eurosystem and have a significant impact on economic activity and inflation (Peersman, 2011,p. 7-8). The ECB used several programs of non-standard monetary policy measures, as a way to a return of inflation rates to levels below, but close to, $2 \%$ over the medium term. (https://www.ecb.europa.eu/home/html/index.en.html).

On July 2, 2009, the Eurosystem launched its first covered bond purchase programme (CBPP1). The programme ended, as planned, in June 30, 2010 when it reached a nominal amount of $€ 60$ billion. The Eurosystem intends to hold the assets bought under this programme until maturity.

On May 10, 2010, the central banks of the Eurosystem started purchasing securities in the context of the Securities Markets Programme $(S M P)$, with a view to addressing the severe tensions in certain market segments which had been hampering the monetary policy transmission mechanism. Following a Governing Council decision in September 6, 
2012 to initiate outright monetary transactions, the SMP was terminated. The existing securities in the SMP portfolio will be held to maturity.

In November 2011, the Eurosystem launched a second covered bond purchase programme (CBPP2). The programme ended, as planned, in October 31, 2012 when it reached a nominal amount of $€ 16.4$ billion. The Eurosystem intends to hold the assets bought under this programme until maturity.

In October 20, 2014 the Eurosystem started to buy covered bonds under a third covered bond purchase programme (CBPP3). The measure helps to enhance the functioning of the monetary policy transmission mechanism, supports financing conditions in the euro area, facilitates credit provision to the real economy and generates positive spillovers to other markets. Since June 2014 the instruments which the ECB have employed are negative interest rates on the deposit facility (current at the level of $-0.40 \%$ ), reinforced form of forward guidance on the evolution of the interest rate corridor in the future.

The expanded asset purchase programme (APP) included all purchase programmes under which private sector securities and public sector securities are purchased to address the risks of too prolonged a period of low inflation. The primary goal of this program was to address the risk of a too long period of low inflation (Jovanović, 2015, p. 181). It consists of the asset-backed securities purchase programme (ABSPP), public sector purchase programme (PSPP), corporate sector purchase programme (CSPP) and third covered bond purchase programme (CBPP3) - Table 1.

ABSPP started in November 21, 2014. The ABSPP helps banks to diversify funding sources and stimulates the issuance of new securities. Asset-backed securities can help banks to fulfil their main role: providing credit to the real economy.

In March 9, 2015 the Eurosystem started to buy public sector securities under the PSPP. The securities covered by the PSPP include: (1) nominal and inflation-linked central government bonds and (2) bonds issued by recognised agencies, regional and local governments, international organisations and multilateral development banks located in the euro area. The Eurosystem intends to allocate $90 \%$ of the total purchases to government bonds and recognised agencies and $10 \%$ to securities issued by international organisations and multilateral development banks (from March 2015 until March 2016 these figures were $88 \%$ and $12 \%$, respectively).

The Eurosystem started to buy corporate sector bonds under the CSPP on June 8, 2016. The measure helps to further strengthen the passthrough of the Eurosystem's asset purchases to financing conditions of 
the real economy, and, in conjunction with the other non-standard monetary policy measures in place, provides further monetary policy accommodation.

Table 1.: Eurosystem holdings under the expanded APP

\begin{tabular}{|c|c|c|c|c|c|}
\hline $\begin{array}{l}\text { Changes of } \\
\text { holdings } \\
\text { (pre vious } \\
\text { month) }\end{array}$ & ABSPP & CBPP3 & CSPP & PSPP & APP \\
\hline $\begin{array}{l}\text { Holdings* } \\
\text { November } \\
2018\end{array}$ & 27,775 & 262,211 & 176,878 & $2,095,560$ & $2,562,424$ \\
\hline $\begin{array}{l}\text { Monthly net } \\
\text { purchases }\end{array}$ & -253 & 508 & 1,507 & 12,961 & 14,723 \\
\hline $\begin{array}{l}\text { Quarter-end } \\
\text { amortisation } \\
\text { adjustment }\end{array}$ & -4 & -519 & -334 & $-6,474$ & $-7,33$ \\
\hline $\begin{array}{l}\text { Holdings* } \\
\text { December } \\
2018\end{array}$ & 27,518 & 262,201 & 178,05 & $2,102,048$ & $2,569,817$ \\
\hline
\end{tabular}

Monthly net purchases of public and private sector securities were conducted at average paces of:

- $€ 60$ billion from March 2015 until March 2016

- $€ 80$ billion from April 2016 until March 2017

- $€ 60$ billion from April 2017 to December 2017

- $€ 30$ billion from January 2018 to September 2018 and

- $€ 15$ billion from October 2018 to December 2018, when Governing Council of the ECB decided to end net purchases. The Governing Council will aim to maintain the size of its cumulative net purchases under each constituent programme of the APP at their respective levels as at the end of December 2018.

The APP is part of a package of measures that also included targeted longer-term refinancing operations (TLTROs), which are Eurosystem operations that provide financing to credit institutions for periods of up to four years. A first series of TLTROs was announced on June 5, 2014 and a second series (TLTRO II) on March 10, 2016.

On July 2, 2009 when the Eurosystem launched its first CBPP1 inflation rate in eurozone was at the annual level of $-0.7 \%$ which was far 
below target (e.g. below, but close to, $2 \%$ over the medium term). According to the inflation figure for December 2018 annual inflation for eurozone is at the level of 1.6\%.In the December 2018 Eurosystem staff macroeconomic projections for the euro area annual inflation is projected at $1.6 \%$ in $2019,1.7 \%$ in 2020 and $1.8 \%$ in 2021 . By implementing all previously mentioned measures the ECB suceed that inflation of eurozone be near target level.

\section{NON-STANDARD MONETARY POLICY MEASURES OF THE BANK OF ENGLAND}

As part of its response to the North Atlantic banking crisis and to a sharp downturn in domestic economic prospects, the Bank of England's (BoE) Monetary Policy Committee (MPC) cut Bank Rate by a factor of ten, from $5 \%$ at the start of October 2008 to $0.5 \%$ on 5 March 2009. But the Committee also decided that it needed to ease monetary conditions further through a program of asset purchases financed by the issuance of central bank reserves (Lyonnet\&Werner, 2012, 97).

The objective of asset purchases of the BoE is to boost the supply of money in the economy, ease conditions in corporate credit markets and, ultimately, to raise the rate of growth of nominal demand and keep inflation on track to meet the $2 \%$ target in the medium term.

At monetary policy meeting, which was held it March 18, 2009, the BoE decided to finance $£ 75$ billion of asset purchases by the creation of central bank reserves by buying gilts to fulfil the overall quantity of purchases. Next increase of the asset purchase program were in May 2009 (by $£ 50$ billion), August 2009 (by $£ 50$ billion), in November 2009 (by $£ 25$ billion), in October 2011 (by $£ 75$ billion), in February 2012 (by $£ 50$ billion) and in July 2012 (by $£ 50$ billion) so the total value of program was at the level of $£ 375$ billion. In August 2016, following the United Kingdom's vote to leave the European Union, Monetary Policy Committee of the BoE decided to implement package of measures designed to provide additional support to growth and to achieve a sustainable return of inflation to the target. This package comprises of: (1) a 25 basis point cut in Bank Rate to 0.25\%; (2) a new Term Funding Scheme to reinforce the pass-through of the cut in Bank Rate; (3) the purchase of up to $£ 10$ billion of UK corporate bonds and (4) an expansion of the asset purchase scheme for UK government bonds of $£ 60$ billion, taking the total stock of these asset purchases to $£ 435$ billion. This package of measures basically addresses uncertainty over Brexit and worries about productivity and economic growth. (https://www.bankofengland.co.uk/) 
In November 2017 Monetary Policy Committee of the BoE raised Bank Rate to the level of $0.50 \%$ and then in August 2018 to $0.75 \%$. To keep inflation low and stable, the Government sets us an inflation target of $2 \%$. In December annual inflation rate stands at $2.1 \%$, which is below rate which was in March 2009 (2.9\% YoY) when the BoE started with asset purchases. In this way asset purchases manages to keep inflation on track to meet the $2 \%$ target in the medium term.

\section{NON-STANDARD MONETARY POLICY MEASURES OF THE BANK OF JAPAN}

Japan was a front-runner of unconventional monetary policy actions, embarking on a policy of quantitative easing in 2001, nowadays followed by major industrialized countries to tackle the recessionary turbulence after the recent global financial crisis (Kimura \& Nakajima, 2013, p. 3).

Non-standard monetary policy measures of the Bank of Japan (BoJ) can be divided on those which are terminated (Quantitative Easing Policy-QE and Comprehensive Monetary Easing-CME) and on those which are still in force (Quantitative and Qualitative Monetary EasingQQE, Expansion of the Quantitative and Qualitative Monetary Easing, Quantitative and Qualitative Monetary Easing with a Negative Interest Rate and Quantitative and Qualitative Monetary Easing with Yield Curve Control) (https://www.boj.or.jp/en/index.htm/).

In March 19, 2001, the BoJ started with implementation of $Q E$, in an attempt to stimulate the nation's stagnant economy. Under this policy the BoJ decided that the main operating target for money market operations be changed from the current uncollateralized overnight call rate to the outstanding balance of the current accounts at the BoJ. Under the new procedures, the Bank provides ample liquidity and the uncollateralized overnight call rate will be determined in the market at a certain level below the ceiling set by the Lombard-type lending facility. When this policy was introduced the BoJ states that the new procedures for money market operations continue to be in place until the consumer price index (excluding perishables, on a nationwide statistics) registers stably a zero percent or an increase year on year. This policy was in force till March 2006.

In October 5, 2010 the BoJ decided to implement a $C M E$ composed of the following three measures. First, change in the guideline for money market operations. The BoJ was encouraged the uncollateralized overnight call rate to remain at around 0 to 0.1 percent. Second, the Bank will maintain the virtually "zero interest rate" policy 
until it judges, on the basis of the "understanding of medium- to long-term price stability," that price stability is in sight, on condition that no problem will be identified in examining risk factors, including the accumulation of financial imbalances. Third, the BoJ established an Asset Purchase Program (APP), which was based on purchases various financial assets, such as government securities, commercial paper (CP), corporate bonds, exchange-traded funds (ETFs) and Japan real estate investment trusts (J-REITs) and to conduct the fixed-rate funds-supplying operation against the pooled collateral. Size of the program was about 35 trillion yen, which is the sum of assets to be newly purchased - about 5 trillion yen - and the size of the fixed-rate funds-supplying operation against pooled collateral - about 30 trillion yen. At the following monetary policy meetings the BoJ increased size of APP: in March 2011 by 5 trillion yen, in August 2011 by 10 trillion yen, in October 2011 by 5 trillion yen, in February 2012 by 10 trillion yen, in April 2012 by 5 trillion yen, in September 2012 by 10 trillion yen, in October 2012 by 11 trillion yen and in December 2012 by 11 trillion yen. The CME finished in April 2013.

In April 2013 the $\mathrm{BoJ}$ introduced of the $Q Q E$ is based on following four elements. First, the adoption of the "monetary base control" by a unanimous vote, which means the BoJ will conduct money market operations so that the monetary base will increase at an annual pace of about 60-70 trillion yen. Second, the Bank will purchase Japanese Government Bond (JGBs) so that their amount outstanding will increase at an annual pace of about 50 trillion yen. Third, the Bank will purchase ETFs and J-REITs so that their amounts outstanding will increase at an annual pace of 1 trillion yen and 30 billion yen respectively. Fourth, the aim of this policy is to achieve the price stability target of 2 percent, as long as it is necessary for maintaining that target in a stable manner.

Since October 2014 the BoJ announced Expansion of the Quantitative and Qualitative Monetary Easing. This policy means following: (1) the Bank will conduct money market operations so that the monetary base will increase at an annual pace of about 80 trillion yen (an addition of about 10-20 trillion yen compared with the past); (2) the Bank will purchase JGBs so that their amount outstanding will increase at an annual pace of about 80 trillion yen (an addition of about 30 trillion yen compared with the past) and (3) The Bank will purchase ETFs and JREITs so that their amounts outstanding will increase at an annual pace of about 3 trillion yen (tripled compared with the past) and about 90 billion yen (tripled compared with the past), respectively.

In January 2016 the BoJ started with implementation of Quantitative and Qualitative Monetary Easing with a Negative Interest Rate, which is based on application a negative interest rate of minus 0.1 
percent to current accounts that financial institutions hold at the Bank. The Bank will continue with QQE with a Negative Interest Rate, aiming to achieve the price stability target of 2 percent, as long as it is necessary for maintaining that target in a stable manner.

The BoJ since September 2016 had been implementing Quantitative and Qualitative Monetary Easing with Yield Curve Control. The new policy framework consists of two major components: the first is "yield curve control" in which the Bank will control short-term and longterm interest rates and the second is an "inflation-overshooting commitment" in which the Bank commits itself to expanding the monetary base until the year-on-year rate of increase in the observed consumer price index (CPI) exceeds the price stability target of 2 percent and stays above the target in a stable manner. In July 2018 the BoJ decided to strengthen its commitment to achieving the price stability target by introducing forward guidance for policy rates and to enhance the sustainability of QQE with Yield Curve Control. The Bank stated that it will maintained the current extremely low levels of short- and long-term interest rates for an extended period of time, taking into account uncertainties regarding economic activity and prices including the effects of the consumption tax hike scheduled to take place in October 2019. Also, the BoJ little changed the policy of long-term interest rates it a sense that the Bank will buy government bonds so that the yield on $10 \mathrm{Y}$ government bonds will remain at around zero level, while allowing greater volatility in the rate of return, increasing the upper yield threshold from $0.1 \%$ to $0.2 \%$. The Bank will continue to purchase JGBs so that their amount outstanding will increase at an annual pace of about 80 trillion yen.

In July 2018 the BoJ has released a projection of inflation rate in Japan and for the fiscal year 2018 rate is forecasted in the range of 1.0$1.2 \%$ (projection in April 2018 was 1.2-1.3\%), for fiscal year 2019 1.8$2.1 \%$ (projection in April 2018 was 2018 2.0-2.3\%) and fiscal 2020 1.9$2.1 \%$ (projection in April 2018 was 2.0-2.3\%). This projection on inflation rate indicates that inflation is still below target of $2 \%$ and that most probably the BoJ will continue with implementation of non-standard monetary policy. 


\section{COMPARATIVE ANALYSIS}

It previous four part of this paper we present non-standard monetary policy for selected central banks (FED, ECB, BoE and BoJ). In the continuation of the paper, we will present a comparative analysis of the application of non-standard measures of monetary policy and the impact of these measures on the stabilization of economic growth. Selected central banks used different programs of non-standard monetary policy as a way to stabilize their economic growth and to bring back inflation to their target level (Table 2).

Table 2.: Economic results of non-standard monetary policy measures

\begin{tabular}{|c|c|c|c|c|c|}
\hline Area & Period & Inflation YoY & GDP Q0Q & $\begin{array}{c}\text { Household debt -\% of GDP } \\
\text { (end of period) }\end{array}$ & $\begin{array}{c}\text { Public debt -\% of } \\
\text { GDP (end of period) }\end{array}$ \\
\hline \multirow{2}{*}{ United States } & Q3 2008 & 4,90 & $-0,50$ & $2008-96,1$ & $2008-72,9$ \\
& Q3 2018 & 2,60 & 0,90 & $2017-77,7$ & $2017-105,4$ \\
\hline \multirow{2}{*}{ Eurozone } & Q3 2008 & 3,60 & 0,10 & $2008-59,2$ & $2008-68,5$ \\
& Q3 2018 & 2,10 & 0,20 & $2017-55,3$ & $2017-86,7$ \\
\hline \multirow{2}{*}{ United } & Q3 2008 & 4,50 & $-0,50$ & $2008-93,3$ & $2008-50,3$ \\
Kingdom & Q3 2018 & 2,20 & 0,60 & $2017-86,3$ & $2017-87,7$ \\
\hline \multirow{2}{*}{ Japan } & Q3 2008 & 2,10 & $-0,10$ & $2008-59,8$ & $2008-191,8$ \\
& Q3 2018 & 1,10 & $-0,60$ & $2017-57,0$ & $2017-253$ \\
\hline
\end{tabular}

Source: ECB Monthly Bulletin and Economic Bulletin and IMF

In Table 2 we present selected indicators for Q3 2008 (this time frame was chosen because Lehman Brothers collapse in September 2008) and for Q3 2018 (the last available data). Data from presented Table 1 indicate that non-standard monetary policy measures influence on lowering inflation rate and increasing economic recovery and stabilizing economic growth (expect for Japan which is still implementing nonconventional monetary policy). In this sense we can accept starting hypothesis that non-standard monetary policy measures have favored economic recovery and the stabilization of economic growth. But on the other hand, household debt as a percent of GDP fell at the end of 2017 in comparison with end of 2008 for all analyzed countries/group of countries, while for the same period public debt rose significantly and is far above legal limitation (e.g. in European Union it is defined by Maastricht criteria that the national debt should not exceed $60 \%$ of GDP). This rise of public debt is very serious problem because can cause new debt crises, as the one in Greece. 


\section{RECOMMENDATION FOR FURTHER ACTION}

The financial crisis and the massive national and supranational response reshaped the world we live in. The best way to prevent future crises is to learn from past experience and to implement all necessary measures as a way to prevent future crises. To do this it is essential to choose right measures and to make their application timely and adequately. Recommendation for further action are following:

- the previous crisis showed that the taxpayers' money for the rescuing of banks that had a problem with liquidity was used to a large extent and that they were acting under principle ,too big to fail". In this way those banks, especially big ones measured by asset level, were confidence that government will intervene and approve them necessary liquidity. As a way to prevent this national and supranational authority should tighten supervisory not only for the banks, but also for entire financial sector (investment and voluntary pension funds, insurance, leasing companies etc.)

- bail-in-method can be consider the continuation of the first proposal. This is essentially where banks commit to stabilizing a failing institution internally, rather than relying on funds from the government and, therefore, the taxpayer.

- further improve regulation, especially for the derivatives market from which crises begin, first in US and then spread on Europe. In that sense, regulators in US had adopted Dodd-Frank Wall Street Reform and Consumer Protection Act in 2010, which brought the most significant changes to financial regulation in the nation since the regulatory reform that came following the Great Recession. In EU in 2012 the European Market Infrastructure Regulation (EMIR) became law with aim to reduce the risks posed to financial systems from the vast of Over the counter (OTC) derivative transactions and the large contingent credit exposures that may arise as a consequence.

- additional improvement of standards for rating agencies, because the big three credit-rating firms (e.g. Standard\&Poors, Moody's and Fitch) came under scrutiny for assigning favorable ratings to risky debt.

- putting stricter regulation on Bitcoin and other crypto currencies. Regulators are probing a number of the players involved in the market, and analysts warn that investments in these currencies could prove worthless. 
All previously mentioned measures indicated that all financial regulators need to be aware of all internal and external influences, to monitor them and to have appropriate reaction. In that sense it is recommendable to set joint action by monetary and fiscal authorities in order to achieve and maintain price and financial stability, regulated public finances and sustainable economic growth and development.

\section{CONCLUSION}

The recent global economic and financial crisis has influence that the main global central banks begin applying non-standard monetary policy measures. These measures were necessary because until then standard monetary policy measures were not responded adequately or the effects of the monetary policy were very weak. The analyzed central banks have applied or still applying nonconventional measures to influence the expansiveness of their monetary policies, stimulate economic growth and development and enable the return of the inflation rate to targeted levels.

The FED by the end of 2008 lowered conventional monetary policy tool, the federal funds rate, at its effective lower bound as the economy was in the midst of a financial crisis and deep recession. In case of the FED non-standard policy actions were intended to put downward pressure on real longer-term interest rates and more generally to improve overall financial and economic conditions.

The ECB used several programs of non-standard monetary policy measures, as a way to a return of inflation rates to levels below, but close to, $2 \%$ over the medium term. According to the inflation figure for December 2018 annual inflation for eurozone is at the level of $1.6 \%$. By implementing all previously mentioned measures the ECB sucessed that inflation of eurozone be near target level.

As a part of economic downturn the $\mathrm{BoE}$ at the beginning of March 2009 decided to decrease bank policy rate at the level of $0.5 \%$. But the Committee also decided that it needed to ease monetary conditions further through a program of asset purchases financed by the issuance of central bank reserves. The objective of asset purchases of the $\mathrm{BoE}$ is to boost the supply of money in the economy, ease conditions in corporate credit markets and, ultimately, to raise the rate of growth of nominal demand and keep inflation on track to meet the $2 \%$ target in the medium term.

The BoJ started with non-standard monetary policy actions in 2001 with aim to fight against deflation and to inflation rate bring back to the target of $2 \%$. According to inflation rate projection for period 2018-

Vol. 21, бpoj 1/2019, стр. 35-52 
2020 the BoJ, which is below target level, probably will continue with application of non-standard monetary measures.

The non-standard monetary policy measures influenced on lowering inflation rate and increasing economic recovery and stabilizing economic growth (expect for Japan which is still implementing nonconventional monetary policy). In this sense we can accept starting hypothesis that non-standard monetary policy measures have favored economic recovery and the stabilization of economic growth. Recommendation for future actions are to tighten supervisory not only for the banks, but also for entire financial sector, continuation of application of bail-in-method, further improvement of regulation, additional improvement of standards for rating agencies and putting stricter regulation on Bitcoin and other crypto currencies.

The main conclusion of using non-standard monetary measures for all selected central banks is that the previously analyzed measures were used in response to the consequences of the recent global and economic crisis and that these impacts would be significantly higher that these measures were not applied. Most of the analyzed central banks have returned to the application of conventional measures because the applied measures have resulted in economic stabilization and the achievement of the inflation target.

\section{REFERENCES}

1. Acharya, V., Eisert, T., Eufinger, C., \& Hirsch, C. (2017). Whatever it takes: The Real Effects of Unconventional Monetary Policy, SAFE Working Paper No. 152, 1-85.

2. Bašić, D. (2011). Novi strategijski pristup u poslovnoj politici banaka kao posledica globanih ekonomskih poremećaja, Ekonomski pogledi, 13(2), 1-18.

3. Borio, C. \& Disyatat, P. (2010). Unconventional Monetary Policies: An Appraisal, The Manchester School 53-89 Supplement 2010, 1-37.

4. Chodorow-Reich, G. (2014). Effects of Unconventional Monetary Policy on Financial Institutions, Brookings Papers on Economic Activity, Spring 2014, 155-227.

5. Economic Bulletin, ECB

6. Engen, E., Laubach, T., \& Reifschneider, D. (2015). The Macroeconomic Effects of the Federal Reserve's Unconventional Monetary Policies, Finance and Economics Discussion Series, Divisions of Research \& Statistics and Monetary Affairs, Federal Reserve Board, Washington, D.C., 1-55. 
7. Federal Reserve Bank of St. Louis https://fred.stlouisfed.org (accessed on January 26, 2019)

8. Fratzscher, M., Lo Duca, M., \& Straub, R. (2014). ECB Unconventional Monetary Policy Actions: Market Impact, International Spillovers and Transmission Channels, 15th Jacques Polak Annual Research Conference, November 13-14, 2014, 184.

9. Gambacorta, L., Hofmann, B., \& Peersman, G. (2014). The Effectiveness of Unconventional Monetary Policy at the Zero Lower Bound: A Cross-Country Analysis, Journal of Money, Credit and Banking, 46(49), 615-642.

10. Giannone, D., Lenza, M., Pill, H., \& Reichlin, L. (2011). NonStandard Monetary Policy Measures and Monetary Developments, ECB Working Paper Series, No 1290 / January 2011, 1-34.

11. IMF www.imf.org (accessed on January 26, 2019)

12. Jovanović, K. (2015). Efekti proširenog programa kupovine sredstava na inflaciju u evrozoni, Ekonomski pogledi, 17(3), 179191.

13. Joyce, M., Miles, D., Scott, A., \& Vayanos, D. (2012). Quantitative Easing and Unconventional Monetary Policy - An Introduction, The Economic Journal, 122 (November), 271-288.

14. Kimura, T. \& Nakajima, J. (2013). Identifying Conventional and Unconventional Monetary Policy Shocks: A Latent Threshold Approach, Bank of Japan Working Paper Series No.13-E-7 May 2013, 1-32.

15. Lenza, M., Pill H., \& Reichlin, L. (2010). Monetary Policy in Exceptional Times, ECB Working Paper Series, No 1253 / October 2010, 1-39.

16. Lyonnet V., \& Werner, R. (2012). Lessons from the Bank of England on 'quantitative easing' and other 'unconventional' monetary policies, International Review of Financial Analysis 25, 94-105.

17. Monthly Bulletin, ECB

18. Peersman, G. (2011). Macroeconomic Effects Of Unconventional Monetary Policy In The Euro Area, ECB Working Paper Series, No 1397 / November 2011, 1-36.

19. Quantitative Easing Definition https://www.investopedia.com/terms/q/quantitative-easing.asp (accessed on January 26, 2019)

20. Santor, E. (2013). Unconventional Monetary Policies: Evolving Practices, Their Effects and Potential Costs, Bank of Canada Review, Spring, 1-15. 
21. Stojković, A., \& Gašić, M. (2012). Odgovor Evropske centralne banke na aktuelnu krizu, Ekonomski pogledi, 12(3), 44-55.

22. The Bank of England https://www.bankofengland.co.uk/ (accessed on December 4, 2018)

23. The Bank of Japan https://www.boj.or.jp/en/index.htm/ (accessed on December 6, 2018)

24. The ECB https://www.ecb.europa.eu/home/html/index.en.html (accessed on December 3-13, 2018)

25. The Federal Reserve System https://www.federalreserve.gov/ (accessed on December 3, 2018)

26. U.S. Bureau of Labor Statistics https://www.bls.gov/ (accessed on December 4-13, 2018) 